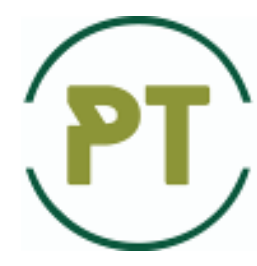

Problems of Tribology, V. 26, No 2/100-2021, 41-49

Problems of Tribology

Website: http://tribology.khnu.km.ua/index.php/ProbTrib

E-mail: tribosenator@gmail.com

DOI: https://doi.org/10.31891/2079-1372-2021-100-2-41-49

\title{
Durability of working bodies of soil-cultivating machines strengthened by composite electrolytic coatings (CEC)
}

\author{
M.S. Stechyshyn ${ }^{1}$, A.O. Kornienko ${ }^{2}$, N.M. Stechyshyna ${ }^{1}$, \\ A.V. Martynyuk ${ }^{1 *}$, M.I. Tsepeniuk ${ }^{3}$, V.O. Herasymenko ${ }^{4}$ \\ ${ }^{1}$ Khmelnitsky National University \\ ${ }^{2}$ National Aviation University \\ ${ }^{3}$ Therpolsky National Technical University named after. I. Pulyuya \\ ${ }^{4}$ Sumy National Agrarian University \\ E-mail: *avmart@khmnu.edu.ua
}

\begin{abstract}
The task of this work is to find the optimal ratio between the size of the particles of silicon carbide and their volumetric content in the nickel matrix to provide maximum characteristics of strength and wear resistance of the working bodies of soil-processing machines.

The article investigates the processes of forming complex electrolytic coatings (CEC) on a nickel basis with particles of the filler of various sizes of silicon carbide (SIC). It has been established that the formation of a sicle size sicle and $\mathrm{SiC}_{5}$ is carried out on a vertical, and all other particles in a horizontal cathode. The volumetric content of $\mathrm{SIC}_{\text {nano }}$ and $\mathrm{SiC}_{5}$ particles in nickel reaches a maximum of about $10 \%$, and $\mathrm{SiC}_{100}-46 \%$.

Cap with particle size $28 / 20$ and $50 / 40 \mu \mathrm{m}$ allow you to get the most wear-resistant coatings. In this case, the coating with particles $28 / 20 \mu \mathrm{m}$ have higher wear resistance, but coating with particles $50 / 40 \mu \mathrm{m}$ are more technological when they are formed.

The size of the filler particles has a significant effect on the tribological characteristics of the CEP, namely wear resistance and friction coefficient. It has been established that the highest wear resistance and the smallest friction coefficients are characterized by coatings having as a filler of fractions $28 / 20$ and $50 / 40 \mu \mathrm{m}$. Tribological studies show the promise and efficiency of the CEP to increase the wear resistance of the working bodies of soil-cultivating machines.
\end{abstract}

Key words: ground-making machines, composite electrolytic coatings (CEC), durability.

\section{Introduction and relevance of the problem}

Physical and mechanical characteristics of the CEC based on a nickel matrix containing a silicon carbide (SIC) are largely determined not only by the geometric dimensions of SIC particles, but also their volumetric content in the nickel matrix. Thus, in [1] it is indicated that there is a proportional dependence between the hardness of particles, their number in a nickel matrix and durability. The maximum strength value is achieved with the optimal content of particles in the coating, the excess of which dramatically reduces the physical and mechanical characteristics of the CEC. Therefore, the task of this work is to find the optimal ratio between the size of the particles of silicon carbide and their volumetric content in the nickel matrix to provide maximum characteristics of strength and wear resistance of the working bodies of soil-processing machines.

\section{Analysis of recent researches}

The problem of increasing the wear resistance of the working bodies of soil-cultivating machines is devoted to a significant number of scientific works [1...4].

Numerical studies indicate the existence of various approaches to solve this problem. Thus, in the paper [1], the issues of strengthening the blades of soil-processing operations of agricultural machines are considered to form the effect of self-combustion, and in [2] distinguish structural, operational and technological methods for Copyright $\odot 2021$ M.S. Stechyshyn, A.O. Kornienko, N.M. Stechyshyna, A.V. Martynyuk, M.I. Tsepeniuk, V.O. Herasymenko. This is an open access article distributed under the Creative Commons Attribution License, which permits unrestricted use, distribution, and reproduction in any medium, provided the original work is properly cited. 
increasing the wear resistance of working bodies of soil-cultivating machines. Technological methods include primarily selection of materials and heat treatment, which provide high wear resistance in conditions of abrasive wear [1 - 4].

In [3], it has been shown that the use according to optimal modes of carbaazonation in a non-hydrogen teaching discharge allowed to increase the wear resistance of the cultivator's paws in 1.7 ...1.8 times.

The author of work [4], the following materials for the manufacture of parts operating in the abrasive mass are recommended: manganese steel (30Г, 50Г, 65Г, 110Г6Х3Л), steel doped chromium (38XА, 40X, 45X, $\mathrm{X} 12, \mathrm{X} 12 \Phi 1, \mathrm{X6BФ),} \mathrm{multicomponent} \mathrm{doped} \mathrm{steel} \mathrm{and} \mathrm{alloys} \mathrm{(12XН3А,} \mathrm{17ХГ2СФР,} \mathrm{08X18H10T),} \mathrm{solid}$ sintered alloys (BK6, BK8, BK15, ВK20).

Technical requirements for discs to domestic technology provides for their manufacture of steel $65 \Gamma$, or its substitute - steel M76 and steel 45 with heat treatment on hardness 39...44 HRC. Disks of foreign manufacturers are made of more durable steels, in particular the discs of the Bellota firms - from the steel 28MnB5, CASE Firms - from Earth Metal. The cost of such disks in 2.0 ... 2.3 times higher than the cost of domestic disks and has $20 \ldots 30 \%$ higher wear resistance [2]. The use of high-quality metals and alloys are economically inappropriate, so the output should be searched in the used methods of surface strengthening of working surfaces.

Surface reinforcement is used to increase wear resistance in cases where there are no increased requirements for the volume strength of parts, but their high surface durability is required.

In agricultural machinery, $90 \%$ of all strengthening works are induction surfacing. The main disadvantage of this method is the high cost of alloys for surfacing [2].

Laps of cultivators are one of the most mass details of the working bodies of agricultural machines. As a result of small service life, a large number of pieces are spent in the form of spare parts, the production of which requires a significant amount of high-quality metal.

In accordance with the technical requirements, the guarantee experience of the archery legs of the cultivator should be no less than 25 hectares, but as shows the practice of exploiting such working bodies, their work for refusal on various soils does not exceed 14 - 19 hectares.

At present, in Ukraine, serial working bodies of soil-cultivating machines are made of steels $65 \Gamma, 45$ and Л53, which in a tempered state (hardness 37 ... 43HRC) have satisfactory indicators of relative elongation but a small boundary of strength $\left(\sigma_{\mathrm{v}}=880 \ldots 1080 \mu \mathrm{Pa}\right)$. According to many years of research and analysis of the results of operating tests of ro-cultivating machines, only for the first year of operation due to breakage (or deformation with subsequent breakage), about $40 \%$ of ploughshare and $15 \%$ shelves, $20 \%$ of cultivators and $30 \%$ of different types of disk working bodies [1].

Studies [5] shows that application for strengthening laser heat treatment allows $1.3 \ldots 1.4$ times reduce the wear of parts of cutting elements in comparison with bulk quenching, and the use of laser surfacing of the Alloy $\Pi \mathrm{C}-14-60+6 \%$ В4C in $1.7 \ldots 1.8$ times compared to the basic induction surfacing technology. Laser technologies provide local heating in the absence or minimum deformations with the next cooling of strengthened products. Receiving high physical and mechanical properties of surface layers is associated with a high heating and cooling rate, which is $104-106^{\circ} \mathrm{C} / \mathrm{s}$.

In general, it can be stated that for most regions of Ukraine, one set of details of the working bodies of soil-cultivating machines is not enough on the current annual cycle (spring + autumn), and therefore it is necessary to continue the searches for new, economically substantiated methods and methods of surface strengthening of the working bodies of soil-cultivating machines.

Thus, the purpose of the study is to develop a technology for strengthening the working bodies of soilcultivating machines by applying composite electrolytic coatings (CEC).

\section{Materials, electrolytes and electrolysis modes when forming a heart}

In the scientific literature, the prospects of use of nickel as a matrix for the next formation of a heap of different composition, filling and properties are noted. Nickel is characterized by high affinity to most types of filler particles. Nickel Based CEC is divided into several types: core, multilayer coatings with increased corrosion resistance in the atmosphere, self-residual coatings, etc.

The analysis of cermetes conducted in [6] indicates a great curiosity of researchers to this type of coatings. In this case, their high thermal resistance and good mechanical properties are noted. Thus, the Ni-SiC coating can operate at a temperature of $2600{ }^{\circ} \mathrm{C}$. A similar coating with a thickness of 200 is firmly coupled with steel and retains hardness (HRC 63) to 260. The coil layer 25 on steel is deformed without hacking with a special steel ball. With multiple immersions of Ni-SiC coated products in water after its heating up to 650 cracks are not formed. The $\mathrm{Ni}-\mathrm{SiC}$ is used instead of a chromium coating and service life while increases several times [6].

It is also noted $[7,8]$ that the cathode extraction of the current and the productivity of the coating process is quite high, and the electrolytes for deposition of nickel are simple and reliable.

Choosing a filler for a chest is determined by the requirements for the properties of the coating: high strength of grip with matrix, affinity with matrix material, corrosion resistance in aggressive environments, highly high mechanical characteristics, etc. 
Such requirements will some extent satisfy the powders of carbides and, in particular, silicon carbide. The silicon carbide is recommended for the creation of compositions to increase the hardness and wear resistance in friction without lubrication and at elevated temperatures [6, 7, 8], corrosion resistance [7]. The silicon carbide in the nickel matrix improves the coating properties: microhardness increases by $1 \ldots 2.5$, internal stresses decreases in $3 \ldots 8$ times, and corrosion resistance increases in $4 \ldots 50$ times [8]. Coverage with silicon carbide has the best grip with steel compared to other fillers. By strength of grip with the base we have such a row: 487-SiC; 213-TiC; 216-Cr7C3 [6].

In addition, silicon carbide has high mechanical characteristics: microhardness $29 \ldots 35$, elastic modulus $\mathrm{E}=394$, border strength to the rupture -180 , to bend $-173 \ldots 225$, on compression -800 [8]. fractions.

The silicon carbide has a low cost and is produced in large quantities in the form of powders packed by

Based on the above, in the work are a nickel base with a filler of sic different fractions from 100/80 to nanoparticles of less than 50. Thus, the $\mathrm{SiC}$ powders with dimensions are used in the work: less than 50 nanoparticles; M5; 28/20; 50/40; 100/80. According to SiC particles in the future, the following designations are given: $\mathrm{Ni}_{-} \mathrm{SiC}_{\text {nano }} ; \mathrm{Ni}-\mathrm{SiC}_{5} ; \mathrm{Ni}-\mathrm{SiC}_{28} ; \mathrm{Ni}-\mathrm{SiC}_{50} ; \mathrm{Ni}-\mathrm{SiC}_{100}$.

For the formation of a cavity on a nickel matrix, sulfate or sulfatchloricular nickel electrolytes $[6,7]$ is used for the most part. The disadvantage of such electrolytes is a low rate of precipitation of nickel: $20 \ldots 40$ with a current density of $0.2 \ldots 0,5$. Increasing current density leads to a deterioration of the quality of the coating.

In this paper, a chloride nickel electrolyte was used, which allows to increase the cathode density of current, increase the rate of depositing nickel [9]. The composition of the electrolyte is given in Table.1.

Table 1

\section{Composition and characteristics of a nickel of electrolyte chloride $[6,7]$}

\begin{tabular}{|c|c|}
\hline Composition of electrolyte, $\mathrm{g} / \mathrm{l}$ & Technological modes of electrolysis \\
\hline $\mathrm{NiCl}_{2} \times 6 \mathrm{H}_{2} \mathrm{O}-300$ & Acidity of $\mathrm{pH} 3 \ldots 4$. \\
$\mathrm{H}_{3} \mathrm{BO}_{3}-40$. & Operating temperature $t=60 \ldots 70{ }^{\circ} \mathrm{C}$. \\
Sodium lauryl sulfate $-0.01 \ldots 0.02$ & Catholic density of current $I_{c}=1 \ldots 3 \mathrm{kA} / \mathrm{m}^{2}$. \\
& Nickel precipitation rate \\
& $\mathrm{U}_{0}=90 \ldots 100 \mu \mathrm{m} / \mathrm{h}$ \\
\hline
\end{tabular}

To the advantages of the selected nickel electrolyte include the stability of the value of $\mathrm{pH}$ throughout the time of electrolysis, which eliminates the effects of acidity change on the volume content of the filler particles into a cavity.

The electrolyte was additionally administered to sodium pair lauryl sulfate in an amount of $0.01 \ldots 0.02$, which according to [8] contributes to the inclusion of $\mathrm{SiC}$ particles in the coating and improves the conditions for increasing the nickel matrix.

Also, the amorphous boron powders were added to the size of the amorphous boron in size about 1 , which is due to the possibility of interaction of boron and nickel with the subsequent heat treatment of coating and obtaining new structures (solid solutions, eutectics, dispersion-solid alloys).

The SiC and B powders were injected directly before the formation of a cavity in an amount from 10 to 110 , depending on the location of the cathode, electrolysis modes, and the required volumetric content of the filler particles in the nickel matrix.

Samples for applying the CEC were made of steel 40X. CEC was applied to the working and side surface of the sample. The choice of the sample form is due to the need to conduct in further tests on the cavitationerosion wear resistance of the obtained coatings for MSV. The same samples were used for electrochemical measurements and potentiostatic studies.

Operational, including tribological and especially cavitation-erosionary characteristics of wear resistance of the CEC depend on the strength of the coupling (adhesion) of the coating with the base. The force of adhesion clutch with a steading base (steel 40X) depends on the degree of surface cleaning from oxides and other chemical compounds. Therefore, before applying CEC, samples are degreased by Viennese lime and subjected to anode treatment for $3 \ldots$ in a $20 \%$ solution of sulfuric acid with a density of current 2.

The general view of the installation for the anodic cleaning of the samples is shown its principal electrical circuit in Fig. 1.

As an anode, nickel plates were used for the formation of the specimens $65 \times 35 \times 5 \mathrm{~mm}$. 


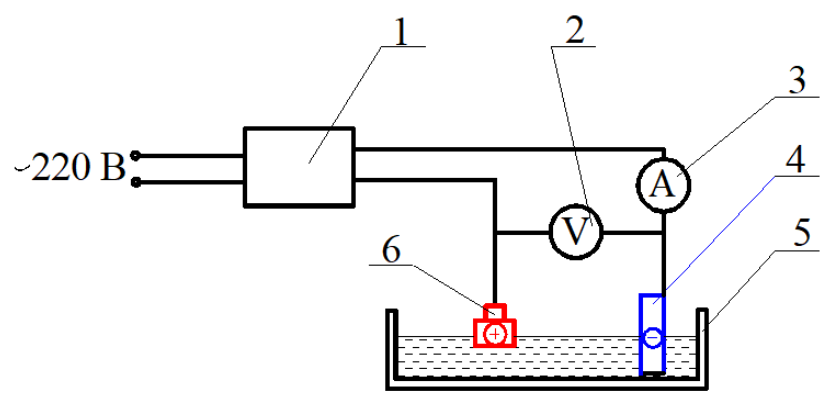

Fig. 1. Principlable electrical scheme of installation

for anodic cleaning of samples before applying CEC:

1 - block of DC power;

2 - voltmeter;

3 - ammeter;

4 - nickel plate;

5 - bath;

6 - sample

The coatings with the inclusion of SiC particles larger than 10 were formed on a horizontal cathode in a pulse mixing mode, and with a particle size of up to 10 on a vertical cathode with a continuous mixing with a magnetic stirrer, for example, a cavity with the inclusion of amorphous boron and particles SiC size 50 and M5 $\left(\mathrm{SiCi}_{\text {nano }}\right.$ and $\left.\mathrm{SiC}_{5}\right)$.

The current density determines the rate of precipitation of the matrix metal. For selected nickel-chloride electrolyte (Table 1), the permissible current density reaches 3, and working-2.0 [7]. According to the results of studies [8], the coatings were carried out with a current density in the range of $0.4 \ldots 1.0$.

To increase the mechanical characteristics of the resulting CEC, their annealed at temperatures above 200. According to [8] at a temperature of 200 and exposure to $1 \ldots 2$ in the Ni-B system are formed by the nickel borid.

The temperature of the formation of eutectics in the Ni-B system is $1060 \ldots 1080$ [8], and therefore annealing in a vacuum in an ОКБ 8086 was performed at a temperature of 1100 , kept $3 . .5$ and cooled together with the furnace.

Formation of the $\mathrm{Ni}-\mathrm{SiC}_{\text {nano }}$ and $\mathrm{Ni}-\mathrm{SiC} 5$ cavity, as well as with the inclusion of amorphous boron, was carried out on a vertical cathode with a continuous stirring of a suspension on the installation developed by us [10]. Formation of cells with particles $\mathrm{SiC}_{28}, \mathrm{SiC}_{50}, \mathrm{SiC}_{100}$ with the addition of amorphous boron powders was carried out on a horizontal cathode. Changing the content of particles in the matrix was regulated by a change in relation and (mixing / sedimentation time) and a change in the concentration of SiC particles and in in the electrolyte.

The number of particles of boron and silicon in the coating was determined by methods of chemical and metallographic analyzes.

The volumetric content of the filler particles depends on the geometric particle sizes. The maiden-shaped users contained as much as $8 \%$ vol. for $\mathrm{SiC}_{\text {nano }}$ and up to $13 \%$ by volume for $\mathrm{SiC}_{5}$.

\section{Testing for friction and wear}

To study the antifriction properties of the composite coatings, the car of M22-M (Fig. 2) was used, which allows in the process of conducting an experiment to automatically record the main characteristics of friction and wear (linear wear of steam and friction coefficient) without removing the sample from the car. As a result, rollers were used in diameter $40 \mathrm{~mm}$, made of tempered steel 45 (HRC 45-48). At a distance of $0.5 \mathrm{~mm}$ from the surface of friction, a chromel-digestive thermopore was injected, which allows you to control the temperature change in the friction zone and judge the stabilization of friction and wear processes. Testing samples with coatings were carried out under friction without mammary according to the scheme of the shaft-plane (Fig. 3), loading with rubbed formed $P=20 ; 40 ; 60 ; 150 \mathrm{~N}$, speed of sliding $v=0.5 \mathrm{~m} / \mathrm{s}$. The rubbing path $L=1 \mathrm{~km}$.

The frictional knot M22-M (Fig.2) consists of a housing 3, in which moving bearings is mounted shaft 11. At the end of the shaft fixing movable contracement 4 . On the housing 3 mobile on bearings mounted carriage 2 , the axis of which coincides with the axis. Rotation of the shaft 11. Caret 2 is fixed by rotation of the carriage 12, interacting with the dynamometer spring 1 . The deformation of the dynamometer spring 1 is controlled by the linear displacement sensor 13, fixed on the rack 14. On the carriage of the carriage 10 in the guide 6 installed assembly 7 with the ability to radial displeasure Regarding the axis of the hall 11. A plant 7 is fixed in a fixed sample 5, which are in conjunction with a mobile countertop 4 . In the hole of a caliper 7 is freely located in a radial direction of rod 8 , one end of which freely rests into the rear side of the sample 5 and the second in the sensor of linear movement 9 , fixed on the bracket 10 . Rod 8 is made of material with a small coefficient of thermal expanded. 


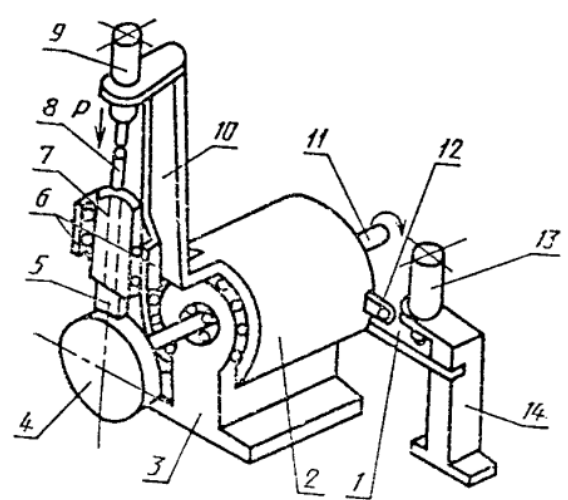

Fig. 2. Scheme of friction node

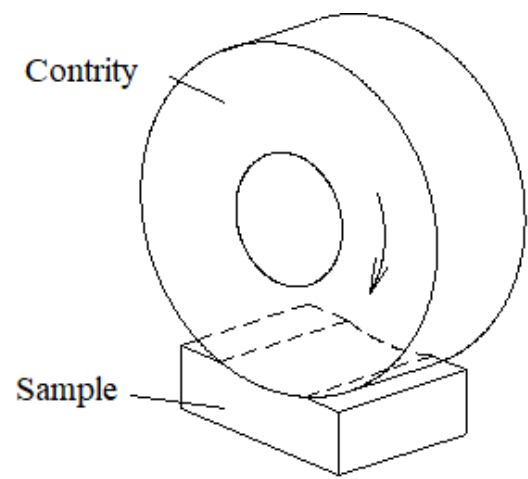

Fig. 3. Scheme friction shaft-plane

The size of the samples on which $10 \times 10 \times 5 \mathrm{~mm}$ test were performed (Fig. 3, Fig. 4). Before testing the sample and the countertoll was washed with gasoline, acetone and alcohol and dried in air. Determined the mass of the sample and counterparted with an error of not more than $0.0005 \mathrm{~g}$. With the help of lab scales (the largest limit of weighing $200 \mathrm{~g}$, weighing error is not more than $0,0005 \mathrm{~g}$ ). In the test process, friction coefficient and linear frictional wear are recorded during sustainable wear. The end of the work was determined by stabilization of temperature and friction coefficient. Recording coefficient of friction and linear wear of frictional steam during test was performed every 5 minutes. The intensity of wearing samples with coatings was evaluated by loss of mass of the sample and the magnitude of linear friction pair [8].

After each test, the counterattack and sample were removed from the machine, washed with gasoline, acetone and alcohol and dried in air. Determined the mass of the sample and counterbalanced with an error of not more than $0.0005 \mathrm{~g}$ by means of laboratory scales.
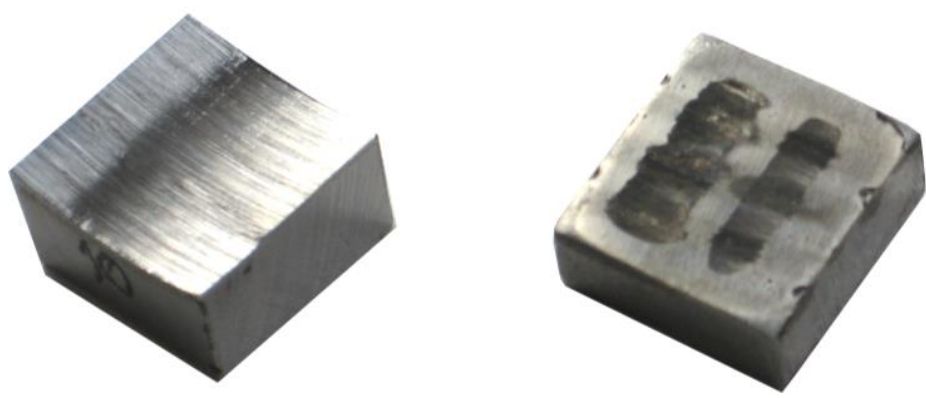

Fig. 4. Samples from a CEC after friction test

The intensity of the wear of the sample and counterticked and $(\mathrm{mg} / \mathrm{km})$ was determined by the formula:

$$
I=\left(m_{1}-m_{2}\right) / L
$$

where: $m_{1}$ - mass of sample (countertick) to test, mg;

$m_{2}-$ mass of sample (countertick) after testing, $\mathrm{mg}$;

$L$ - rubbing path, $\mathrm{km}$.

\section{Research results}

Physical and mechanical characteristics of the CEC based on a nickel matrix containing a silicon carbide (SiC) are largely determined not only by the geometric dimensions of $\mathrm{SiC}$ particles, but also their volumetric content in the nickel matrix. Thus, in [7], it is indicated that there is a proportional dependence between the hardness of particles, their number in a nickel matrix and durability. The maximum strength value is achieved with the optimal content of particles in the coating, the excess of which dramatically reduces the physical and mechanical characteristics of the CEC.

Thus, the coating on a nickel base with particles of sic different fractions and for convenience, we will denote coating by the size of the filler particles. For example, nickel bp with particles SiC fractions $5 / 10 \mu \mathrm{m}$, denote both $\mathrm{Ni}+\mathrm{SiC}_{5}$, fractions $28 / 20 \mu \mathrm{m}$ as $\mathrm{Ni}+\mathrm{SiC}_{28}, 50 / 40 \mu \mathrm{M}-\mathrm{Ni}+\mathrm{SiC}_{50}, 100 / 80-\mathrm{Ni}+\mathrm{SiC}_{100}$, and

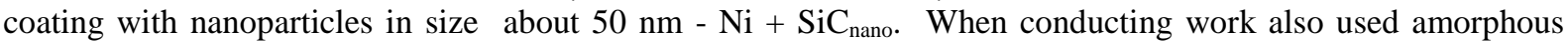
boron dispersion of about $1 \mu \mathrm{m}$. 
Studies have shown that the size of the filler particles has a significant impact on the wear resistance of the coating. According to the results of experiments, the largest linear wear with loads of 20 and $40 \mathrm{~N}$ have specimens from steel $40 \mathrm{X}$ without coating. When applied to a steel layer of galvanic nickel, which has a hardness $\mathrm{H} \mu=2.4 \ldots 2.7 \mathrm{GPa}$, linear friction pair decreases by 1.4 times, weight demolition of the sample - by 2 times, and countertil in 3 ... 7.6 times Compared to test samples without coating (Fig. 5).

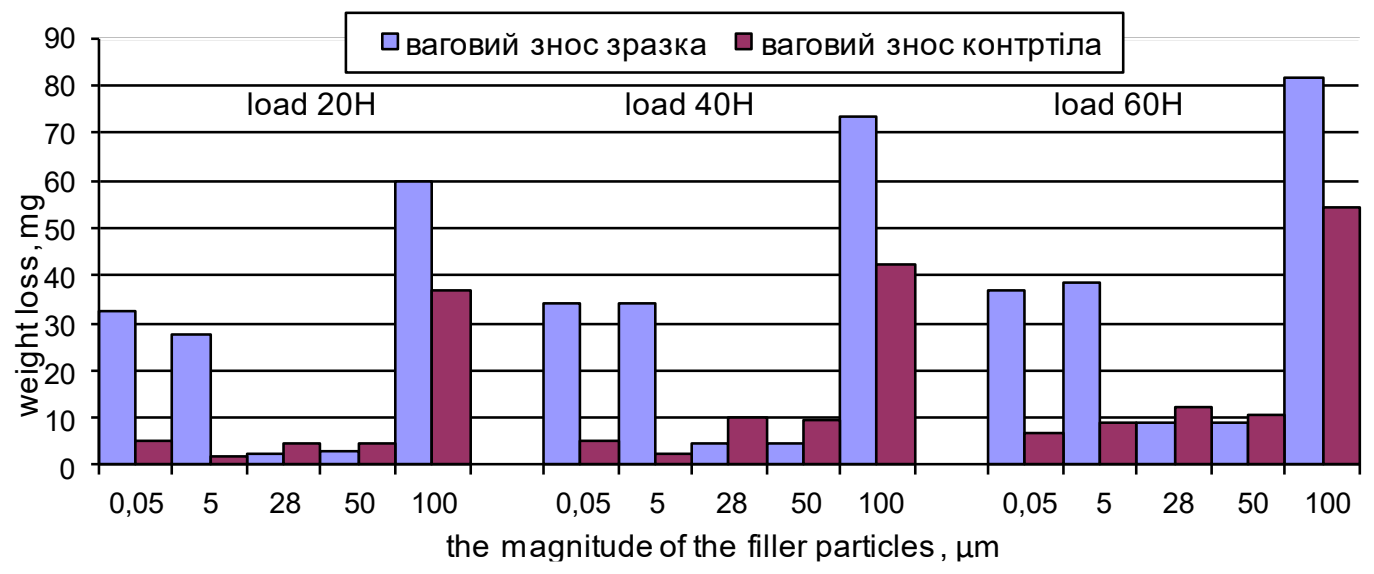

a

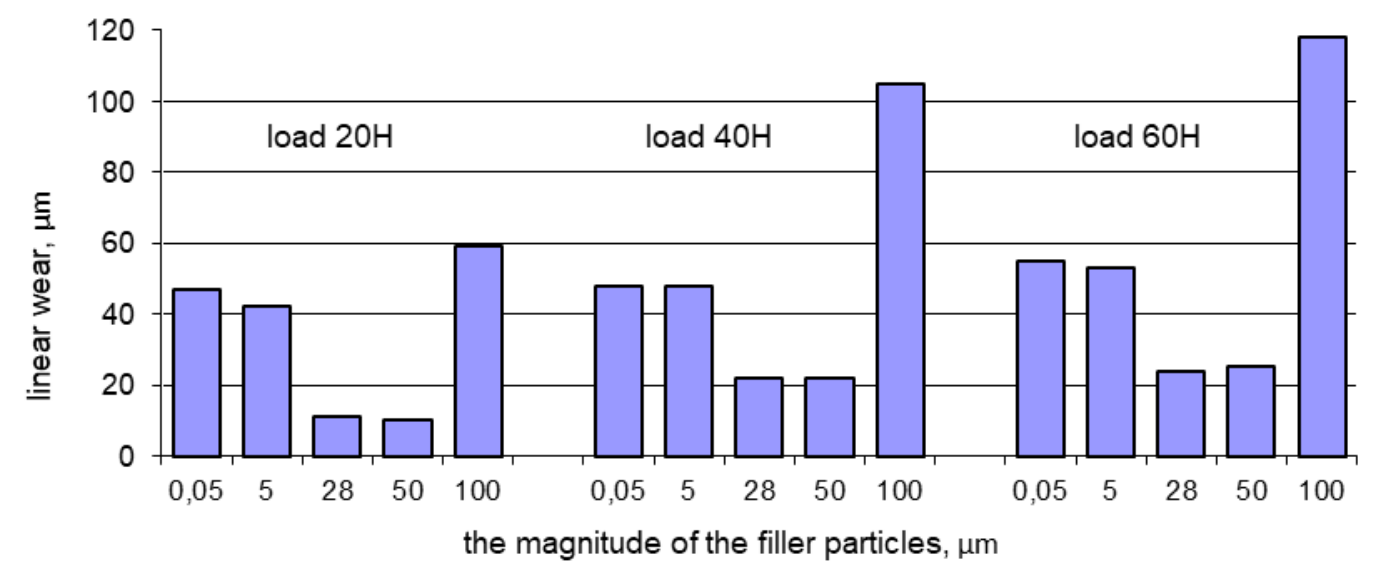

b

Fig. 5. Wearing resistance of $\mathrm{Ni}-\mathrm{SiC} \mathrm{CEC}$, depending on the size of the filler: a - weight wear of the sample and countertick, mg / km; $\mathrm{b}$ - linear friction pair of friction, $\mu \mathrm{m} / \mathrm{km}$

Wearing resistance of samples from the CEC containing the SiC filler of different fractions is higher than in purely nickel coatings. So, for samples with the inclusion of a fraction of $100 / 80 \mu \mathrm{m}$ there is a significant weight and linear wear, which even exceeds the wear of the sample without coating. The hardness of the matrix with this slightly increased and is $\mathrm{H} \mu=2,8-3,0 \mathrm{GPa}$, that is, increased by $10-15 \%$ compared with a clean nickel due to composite strengthening and larger stresses in the matrix. The obtained results are explained by the fact that the size of the particles is compared with the coating thickness $(200-300 \mu \mathrm{m})$ and in these conditions, the plastic nickel matrix can not compensate for contact loads on large SiC particles, which leads to fragile destruction and distorting. In addition, the volumetric content of $\mathrm{SiC}_{100}$ particles in the coating is the largest compared to other test samples and is $46 \%$. Under such a carbide content, significant stresses that the plastic matrix can not be compensated effectively.

A large weight wear of the sample is observed in the application as a filler for small particles of fraction less than $5 \mu \mathrm{m}$ and nanoparticles $50 \mathrm{~nm}$ (Fig. 5). The use of such particles slightly increases the wear resistance of the coating in comparison with galvanic nickel, but not significantly (a decrease in weight loss of the sample is $10-20 \%$ ) because the content of $\mathrm{SiC}_{5}$ particles and $\mathrm{SiC}_{\text {nano }}$ was 8 and $3 \mathrm{vol} \%$ respectively, that is, it is less than large particles and such particles are more efficiently strengthening the matrix (disperse hardening occurs) than increasing wear resistance in comparison with larger particles. This is due to the fact that in such compositions, the particle size is smaller than the size of individual contact spots, they can not effectively perceive the load and therefore the main contribution to wear resistance introduces the NI matrix, which has low mechanical properties and due to the emergence of significant stresses possible occurrence of cracks [8] . 
The highest wear resistance among the above coatings have a cap with the inclusion of fractions 28/20 and $50 / 40 \mu \mathrm{m}$ that have the smallest wear with all loads. The content of the filler in such coatings is, respectively, 24 and $28 \mathrm{vol} \%$. In this case, slightly less wear is covered with the inclusion of a fraction of 28/20 $\mu \mathrm{m}$. Weight wear of such samples is an order of magnitude smaller than for coatings with smaller and large particles. Compared to galvanic nickel, such coatings have a decrease in wear 12,9 and 5 times with loads of 20, 40, 60 N, respectively (Fig. 5).

The highest wear resistance of coatings with inclusion of $28 \ldots 50 \mu \mathrm{m}$ may be due to the distribution of load they perceive. The solid inclusion load is equal to the actual contact pressure when their sizes are smaller or vessel with a single contact spot $(2-10 \mu \mathrm{m})$. For compositions with optimal particle sizes $(28 \mu \mathrm{m})$ there are no processes of seizing, abrasive and fragile destruction and there is a normal mechano-oxidation process of wear.

In addition to wear resistance, an important tribotechnical parameter is the coefficient of friction $\mathrm{f}$. An analysis of the test results showed that the coefficient of friction significantly affects the load when the SiC filler and the size of the SiC filler and clearly follows such a regularity that with an increase in loading such as friction decreases (Fig. 6). This is due to the fact that with an increase in normal load n, the friction force FTR increases not so significantly and, accordingly, the ratio $f=F_{t r} / N$ decreases.

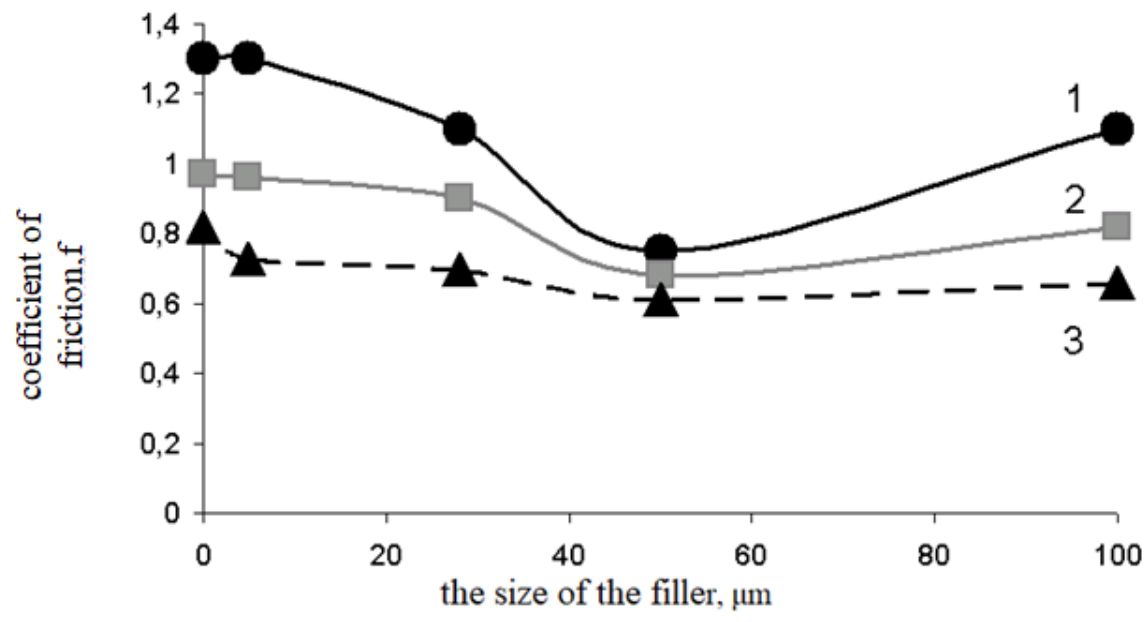

Fig. 6. Dependence of coefficient of friction $f$ from the size of the particles of the filler CEC:

$1-\operatorname{load} 20 \mathrm{n}$;

$2-40 \mathrm{~N}$ and $3-60 \mathrm{~N}$

As to the influence of the size of the particles of the filler of the CEC on the friction coefficient $\mathrm{F}$, it can be noted that the friction coefficient decreases and for the range of particles of filler $40 \ldots 60 \mu \mathrm{m}$ friction coefficient is minimal. For coatings with larger filler particles (fraction 100/80) friction coefficient is greater. This can be explained by the fact that for small particles of the contact spot is greater than the size of the particles and friction occurs on a nickel matrix that has a high friction coefficient and is prone to gripping. For particles of larger than $10 \mu \mathrm{m}$, the size of the contact is smaller than the size of the particles and the main contribution to the friction is introduced by the filler particles, which contributes to the reduction of friction coefficient and increased wear resistance. For large particles it is possible to distort them and the abrasive destruction begins. It can also be noted that for greater loads $(60 \mathrm{~N})$, the effect of the size of the filler particles on the friction coefficient decreases, while there is a greater difference between the friction coefficients of nickel coatings $(F=0.82)$ and filling coes $(F=0.73$ and below $)$. . Probably, with larger loads of solid particles, the filler begins to perceive more efficiently load, which in turn positively affects the friction processes.

\section{Practical recommendations}

1.Formation of a sac with particles $\mathrm{SiC}_{n}$ nano and $\mathrm{SiC}_{5}$ is carried out on a vertical, and all other particles in a horizontal cathode. With such particles, we obtain the highest corrosion resistance of the coating.

2.The volumetric content of particles $\mathrm{SiC}_{n a n o}$ and $\mathrm{SiC}_{5}$ in nickel reaches a maximum of about $10 \%$, and $\mathrm{SiC}_{100}-46 \%$.

3.Cap with particle size $28 / 20$ and $50 / 40 \mu \mathrm{m}$ allow you to get the most wear-resistant coatings. In this case, the coating with particles $28 / 20 \mu \mathrm{m}$ have higher wear resistance, but coating with particles $50 / 40 \mu \mathrm{m}$ are more technological when they are formed. 


\section{Conclusions}

1.Sumulary of filler particles has a significant effect on the tribological characteristics of the CEC, namely wear resistance and friction coefficient. It has been established that the highest wear resistance and the smallest friction coefficients are characterized by coatings having as a filler of fractions $28 / 20$ and $50 / 40 \mu \mathrm{m}$.

2.Tribological studies show the promise and efficiency of the use of a cavity to increase the wear resistance of the working bodies of soil-cultivating machines.

\section{References}

1.Denisenko M.I., Vojtyuk V.D. Zmicnennya lez gruntoobrobnih robochih organiv sil's'kogospodars'kih mashin z utvorennyam efektu samozagostryuvannya. Tekhnichnij servis agropromislovogo, lisovogo ta transportnogo kompleksiv. №6, 2016. - S.175-182.

2.Borak K.V. Pidvishchennya nadijnosti robochih organiv Iruntoobrobnih mashin/ K.V. Borak// Visnik Harkivs'kogo nacional'nogo tekhnichnogo universitetu sil's'kogo gospodarstva imeni Petra Vasilenka. -2015. Vip. 163. - S. $120-125$.

3.Stechishin M.S. Znosostijkist' lap kul'tivatora, shcho modifikovani azotuvannyam v tliyuchomu rozryadi / M.S. Stechishin, M.V. Luk'yanyuk, V.P. Oleksandrenko, A.V. Martinyuk, YU.M. Bilik // Sil's'kogospodars'ki mashini: Zb. nauk. statej. - Vip. 44. - Luc'k, 2020. - S.123-134.

4.Volkov YU.V. Dolgovechnost' mashin rabotayushchih v abrazivnoj srede / YU.V. Volkov, Z.A. Volkova, L.M. Kajgorodcev. - M.: Mashinostroenie, 1994. - 117 s.

5.Aulin V.V. Teoretichni osnovi samozagostryuvannya, micnosti i znoshuvannya rizal'nih elementiv ROGM ta napryamki pidvishchennya ïh dovgovichnosti / V.V. Aulin, V.M. Bobric'kij, A.A. Tihij/ Visnik in- zhenernoï akademiï Ukraïni. - 2010. - № 1. - S. 149-154.

6.Sajfullin R.S. Kompozicionnye pokrytiya i materialy / R.S. Sajfullin. -M.: Himiya, 1977. -272 s.

7.Antropov L.I. Kompozicionnye elektrohimicheskie pokrytiya i materialy / L.I. Antropov, YU.N. Lebedinskij. -K.: Tekhnika, 1986. -200 s.

8.Kornienko A.O. Formuvannya tribotekhnichnih vlastivostej kompozicijnih elektrolitichnih pokrittiv na osnovi nikelyu stvorennyam gradientnih struktur / A.O. Kornienko. Avtoref. dis.kand. tekhn. nauk. -K, 2007. $21 \mathrm{~s}$.

9.Yavors'kij V.T. Elektrohimichne nanesennya metalevih, konversijnih ta kompozicijnih pokrittiv / V.T. YAvors'kij, O.I. Kuntij, M.S. Homa. -L'viv: «L'vivs'ka politekhnika», 2000. -216 s.

10. Pat. 55154 Ukraïna, MPK C25D11/00; C25D15/00. Gal'vanichna ustanovka dlya nanesennya kompozicijnih elektrolitichnih pokrittiv / Stechishin M.S., Bilik YU.M. -U201005565; zayavl.07.05.2010; opubl. 10.12.2010, Byul.№23. 
Стечишин М.С., Корніснко А. О., Стечишина Н.М., Мартинюк А.В., Цепенюк М.I., Герасименко В. О. Зносостійкість робочих органів грунтообробних машин зміцнених нанесенням КЕП

У статті досліджено процеси формування комплексних електролітичних покриттів (КЕП) на нікелевій основі з частинками наповнювача різних розмірів карбідом кремнію (SiC). Встановлено,що формування КЕП з розмірами $\mathrm{SiC}_{\text {нано }} \mathrm{i} \mathrm{SiC}_{5}$ проводиться на вертикальному, а усіх інших за розміром частинок на горизонтальному катоді. Об'ємний вміст частинок $\mathrm{SiC}_{\text {нано }}$ i $\mathrm{SiC}_{5}$ в нікелі сягає максимуму в середньому біля $10 \%$, а $\mathrm{SiC}_{100}-46 \%$.

КЕП 3 розмірами частинок $28 / 20$ та 50/40 мкм дозволяють отримати найбільш зносостійкі покриття. При цьому покриття 3 частинками 28/20 мкм мають вищу зносостійкість, але покриття 3 частинками 50/40 мкм є більш технологічними при їх формуванні.

Розмір частинок наповнювача має значний вплив на трибологічні характеристики КЕП, а саме зносостійкість та коефіцієнт тертя. Встановлено, що найвищою зносостійкістю та найменшими коефіцієнтами тертя характеризуються покриття, що мають у якості наповнювача порошки фракцій 28/20 та 50/40 мкм. Трибологічні дослідження показують перспективність і ефективність застосування КЕП для підвищення зносостійкості робочих органів грунтообробних машин.

Ключові слова: грунтообробні машини, зносостійкість, формування комплексних електролітичних покриттів 